\title{
MOBILISASI DUKUNGAN PADA PILKADA SERENTAK 2018 : PERBANDINGAN KEMENANGAN DAN KEKALAHAN KOLOM KOSONG DI KOTA MAKASSAR DAN KOTA TANGERANG
}

\author{
Ananda Rizki Amelia \\ Jurusan Ilmu Politik, Fisip, Universitas Andalas \\ Email : aramelia10@gmail.com
}

\begin{abstract}
Abstrak
Fenomena kelompok pendukung kolom kosong pada gelombang ketiga pilkada serentak 2018 di Kota Makassar dan Kota Tangerang. Penelitian ini bertujuan mendeskripsikan dan menganalisis tipe mobilisasi kelompok pendukung kolom kosong yang memiliki proses mobilisasi dan hasil yang berbeda. Hasil penelitian ini menunjukkan bahwa Kemenangan dan kekalahan kolom kosong di Kota Makassar dan Kota Tangerang tidak terlepas dari peran mobilisasi massa dari kelompok pendukung kolom kosong yaitu Relawan Kolom Kosong (Rewako) di Kota Makassar dan jaringan Kotak Kosong (JKK) di Kota Tangerang. Bahwa upaya mobilisasi massa yang dilakukan Rewako merupakan tipe mobilisasi Patron-Klien dan mesin politik, Danny Pomanto sebagai patron dan sebagian besar masyarakat kota Makassar menjadi kliennya. Berbeda dengan Kota Tangerang, gerakan JKK tidak didukung oleh elit politik setempat, mereka memobilisasi gerakan ini dinilai sebagai partisipasi otonom dari masyarakat yang hingga hari ini menjadi oposisi pemerintahan Kota Tangerang tidak didukung oleh elit partai manapun. Walau hasil perolehan pilkada di kedua daerah tersebut berbeda, dalam prosesnya Rewako dan JKK berhasil memobilisasi massa untuk berperan aktif menentukan hasil pilkada dengan memilih kolom kosong.

Kata Kunci : Mobilisasi Massa; Kolom Kosong; Elit Politik
\end{abstract}

\begin{abstract}
The phenomenon of empty column support groups on the third wave of 2018 simultaneous local elections in Makassar City and Tangerang City. This study aims to describe and analyze the type of mobilization of empty column support groups that have different mobilization processes and results. The results of this study indicate that the victory and defeat of the empty column in Makassar City and Tangerang City is inseparable from the role of mass mobilization from the empty column support groups namely Empty Column Volunteers (Rewako) in Makassar City and the Empty Box network (JKK) in Tangerang City. Whereas Rewako's mass mobilization efforts are a type of Patron-Client mobilization and political machine, Danny Pomanto as a patron and most of the people of Makassar city are his clients. Unlike the City of Tangerang, the JKK movement was not supported by local political elites, they mobilized this movement as an autonomous participation of the people who until now became the opposition of the Tangerang City government not supported by any party elites. Although the results of the elections in the two regions were different, in the process Rewako and JKK succeeded in mobilizing the masses to play an active role in determining the results of the elections by selecting an empty column.
\end{abstract}

Keywords: Mass Mobilization; Empty Column; Political Elite; 


\section{PENDAHULUAN}

Pemilihan umum yang dilaksanakan untuk memilih kepala daerah secara langsung sebagai bentuk perwujudan demokrasi lokal di daerah dan menjadi salah satu ukuran tingkat partisipasi politik masyarakat daerah, pemilihan kepala daerah menjadi momentum yang menentukan proses demokrasi di daerah tersebut. Pemilihan umum kepala daerah secara langsung merupakan instrumen yang sangat penting dalam penyelenggaraan pemerintahan daerah. Pada tahun 2015, Pilkada telah memasuki periode ketiga sejak dimulai pada tahun 2005. Semenjak tahun 2005, berbagai evaluasi dan kritik terhadap pelaksanaan Pilkada di ratusan daerah kabupaten atau kota dan provinsi telah ditelaah. Pemilihan kepala daerah secara serentak dilaksanakan sesuai amanat Undang-Undang No 8 tahun 2015 tentang Pemilihan Gubernur, Bupati, dan Wali Kota. Dalam Undang- Undang tersebut dijelaskan bahwa pemilihan gubernur, bupati, dan wali kota dilaksanakan secara serentak dan bertujuan untuk menghemat anggaran Negara ${ }^{1}$.

Hadirnya calon tunggal merupakan implementasi dari keputusan MK Nomor 100/PUU- XIII/2015 yang secara langsung membatalkan UU Nomor 8 tahun 2015 tentang Pemilihan Kepala Daerah Gubernur, Bupati, dan Walikota yang menyebut bahwa pelaksanaan pilkada hanya dapat berjalan minimal adanya dua pasangan calon. Pertumbuhan calon tunggal meingkat sejak Pilkada Serentak pertama kali dilaksanakan secara bertahap dimulai sejak tahun 2015. Pada tahun 2018 sebanyak 171 daerah terdiri dari 17 provinsi, 115 kabupaten dan 39 kota yang melaksanakan pemilihan kepala daerah serentak pada tanggal 27 Juni 2018. Setidaknya ada 581 pasangan calon yang memperebutkan 171 posisi kepala daerah pada pilkada serentak untuk ketiga kalinya tersebut. Pilkada serentak 2018 mewariskan catatan penting bagi perkembangan demokrasi dalam negeri. Sebab, menurut data Komisi Pemilihan Umum (KPU) RI menunjukkan, dari 171 daerah yang akan menggelar pilkada serentak, terdapat enam belas daerah yang hanya memiliki satu pasangan calon atau calon tunggal.

Kelompok pendukung kolom kosong tersebut ialah bagian dari proses partisipasi politik, karena perilaku warga negara dalam pemilihan umum setidaknya menjadi indikator yang dapat diukur intensitasnya sebagai bentuk partisipasi politik ${ }^{2}$. Terdapat 15 daerah yang dimenangkan oleh calon tunggal dan hanya 1 daerah yang dimenangkan oleh kotak kosong. Selain itu, terlihat pula hadirnya kelompok kolom kosong di 10 daerah dari 16 jumlah daerah pilkada 2018. Dengan penamaan kelompok yang beragam, mereka secara langsung terlibat dalam proses pemilihan dari awal penentuan calon tunggal, masa kampanye, hingga waktu pemilihan dan penghitungan. Terlebih terdapat satu daerah yang dimenangkan oleh kelompok Kolom Kosong melawan calon tunggal yaitu, Kota Makassar. Sehingga Kota Makassar hingga tahun 2020 tidak dipimpin oleh Walikota dan Wakil Walikota pilihan masyarakat, melainkan Pelaksana

\footnotetext{
${ }^{1}$ Tjahjo Kumolo, 2015, Politik Hukum Pilkada Serentak, Jakarta: PT. Mizan Republika, hlm. 82

${ }^{2}$ Miriam Budiardjo, 2008, Dasar-dasar Ilmu Politik, Jakarta: Gramedia, hlm. 368
} 
Tugas (plt) yang didelegasikan oleh Kementerian Dalam negeri (Kemendag RI). Fenomena ini merupakan kali pertama dalam sejarah pilkada tanahair.

Fenomena munculnya calon tunggal tersebut ternyata memicu lahirnya aksi-aksi kolektif yang mengorganisir diri untuk bersosialisasi kepada masyarakat tentang kolom kosong. Hal ini bertujuan untuk mengajak masyarakat yang tidak setuju dengan calon tunggal atau kecewa dengan pasangan calon bisa memilih kolom kosong sebagai alternatif. Direktur Riset Monitor Indonesia berpendapat bahwa kelompok kolom kosong merupakan alarm bagi aktor politik. Pasalnya, kemunculan kolom kosong biasanya selalu didasarkan tiga kondisi; pertama, adanya pihak-pihak yang sengaja mendesai munculnya calon tunggal. Dalam studi yang dilakukan Dur dan Bievre, pihak tersebut ialah kelompok berkepentingan dalam menguasai bisnis, dinasti politik, dominasi, pemburuan rente, ataupun lainnya. Kedua, gagalnya kaderisasi parpol. Parpol kehabisan stok kader yang secara kalkulasi politik mampu bersaing di pilkada. Salah satu variabel penting dalam mengusung kandidat adalah soal peluang menang, hal ini sesuai pandangan Strom (1990) bahwa logika partai dalam pemilu selalu ditujukan untuk memperoleh kemenangan. Ketiga, politik berbiaya mahal. Ongkos demokrasi electoral yang begitu mahal membuat sejumlah tokoh enggan bertarung ${ }^{3}$. Mobilisasi dukungan yang dilakukan dalam upaya memenangkan kontestasi pemilihan kepala daerah di Kota Makassar dan Kota Tangerang pada tahun 2018 menjadi menarik untuk diteliti

\section{Mobilisasi Politik dalam Kontestasi Pilkada}

Aktifitas mobilisasi politik tidak harus berangkat dari kekuatan partai politik. Organisasi non partai atau organisasi kemasyarakatan tentu memiliki pengaruh dalam memobilisasi massa dalam sebuah gerakan sosial yang bertujuan untuk kepentingan masyarakat. Dengan kekuatan massa yang dimilikinya ini dapat digunakan sebagai mesinmesin politik yang efektif dalam kontestasi politik. Hal ini lah yang menegaskan bahwa mobilisasi politik merupakan kunci dari memenangkan kontestasi pemilu ${ }^{4}$.

Dalam negara yang menganut demokrasi sebagai sistem politiknya, serangkaian aktifitas warga negara untuk aktif terlibat secara sadar tanpa paksaan dalam proses-proses demokrasi bisa disebut sebagai mobilisasi politik dalam konteks partisipasi ${ }^{5}$ Lebih dalam, Samuel Huntington dan Nelson menjelaskan bahwa partisipasi poiltik masyarakat di dasarkan atas dua kecenderungan, yaitu atas dasar kesadaran yang kemudian melahirkan partisipasi yang otonom (autonomous participation) dan atas dasar ajakan atau digerakkan orang lain (mobilized participation) ${ }^{6}$. Mobilisasi politik adalah orangorang yang di mobilisasikan dirangsang untuk bertingkah laku untuk mempengaruhi pemerintah, tanpa mereka secara pribadi menaruh minat terhadap, atau malahan harus

\footnotetext{
${ }^{3}$ Kotak Kosong dan Pseudo Demokrasi, dimuat 4 Juli 2018, https://beritagar.id/artikel/telatah/kotakkosong-dan-pseudo-demokrasi, diakses pada 13 Mei 2019 pukul 16.55 WIB

${ }^{4}$ Moh. Fachrul Ananda, Mobilisasi Politik: Ormas dalam Kontestasi Politik Pemilihan Gubernur Jawa Timur 2018, Jurnal Fakultas Ilmu Sosial dan Ilmu Politik Universitas Airlangga, P.14 No. 19, hlm. 6

${ }^{5}$ Miriam Budiardjo, 1982, Partisipasi dan Partai Politik, Gramedia, Jakarta, hlm. 92

${ }^{6}$ Samuel P. Huntington dan Joan Nelson, 1990, Partisipasi Politik di Negara Berkembang, Jakarta: Rineka Cipta, hlm. 9
} 
menyadari dampak tindakan mereka itu terhadap pemerintah. Mereka bertindak atas instruksi, dan mereka untuk sebagian besar atau sepenuhnya digerakkan oleh loyalitas, rasa cinta, rasa hormat, atau rasa takut, terhadap seorang pemimpin, atau oleh hasrat untuk memperoleh manfaat-manfaat yang mereka percaya dapat diberikan oleh pemimpin itu. Beberapa kategori hubungan pemimpin-pengikut yang berbeda satu sama lain memberikan landasan untuk mobilisasi. Tiga diantara yang adalah: ikatan antara pemimpin-pemimpin tradisional dan pengikut pengikut mereka, hubungan patronklien, dan political machine (alat partai politik) ${ }^{7}$.

Menurut Samuel Huntington dan Nelson mobilisasi dikategorikan dalam 3 bentuk, yakni ikatan tradisional, hubungan patron-klien, dan political machine (mesin politik) berikut penjelasan kategori mobilisasi politik ${ }^{8}$ : Pertama, Ikatan tradisional adalah ikatan-ikatan antara sejumlah pengikut dan seorang pemimpin yang ditentukan dan disahkan oleh tradisi kebudayaan, sosial atau keagamaan yang sudah tua. Pengikutpengikut pemimpin tradisional berkewajiban untuk menghormati dan menyegani mereka tak peduli apakah pemimpin-pemimpin itu telah berbuat baik terhadap mereka atau mengenal mereka secara pribadi. Kedua, Hubungan patron-klien diikat secara individual dan di dasarkan atas pertukaran manfaat yang timbal balik tapi timpang. Patron yang berstatus lebih tinggi memberikan perlindungan, bantuan ekonomi, dan pantulan status kepada kliennya, dan turun tangan atas nama mereka untuk berhubungan dengan pejabat-pejabat pemerintah. Klien klien membalas mereka dengan loyalitas dan sikap hormat, dengan tenaga kerja, dengan memberikan hadiahhadiah kecil dari waktu ke waktu, dan dengan memberikan dukungan politik ${ }^{9}$.

Konsep klientalisme sering ditempatkan dalam posisi yang memiliki arti berbeda dengan patronase (patronage). Konsep patronase didefinisikan sebagai relasi dua arah ketika seorang yang memiliki status sosial ekonomi yang lebih tinggi (patron) menggunakan pengaruh dan sumber daya yang dimilikinya untuk memberikan perlindungan pada orang lain yang memiliki status sosial ekonomi yang lebih rendah (klien) yang memberikan dukungan dan bantuan kepada patron ${ }^{10}$. Dari pendapat ahli, dapat diketahui bahwa klientelisme memiliki beberapa elemen kunci. Tiga elemen klientelisme yaitu iterasi, asimetri, dan resiprositas. Ketiga, Political machine (mesin politik) secara historis, machine semacam itu merupakan alat untuk memobilisasikan partipasi massal dikalangan kaum miskin di kota. Melalui ward boss (pentolan partai di tiap daerah pemilihan dalam kota), machine menawarkan kepada orang-orang miskin banyak manfaat yang sama yang biasanya ditawarkan oleh seorang patron. Sebagai imbalannya, orang miskin itu diharapkan untuk memberikan suaranya sesuai dengan intruksi boss itu. Munculnya political machine (mesin politik) di kota-kota besar Amerika biasanya dapat di telusuri kembali asal-mulanya kepada banyaknya imigran miskin dan tidak berpengetahuan yang menetap di kota-kota, heterogenitas etnis penduduk kota,

\footnotetext{
${ }^{7}$ Ibid., hlm. 173

${ }^{8}$ Ibid., hlm. 173

${ }^{9}$ Loc. Cit. Huntington, hlm. 175

${ }^{10}$ Dyah Laily Fardisa, 2017, Membongkar Jaringan Politik Dalam Tubuh Bisnis, dalam Rekha Adji Pratama, "Patronase Dan Klientalisme Dalam Relasi Walikota, Pejabat Birokrasi, dan Masyarakat di Kota Kendari tahun 2017”. Yogyakarta: Universitas Gadjah Mada, hlm. 18
} 
meluasnya hak pilih, adanya patronase yang luas, dan tidak memadainya otoritas dan kekuasaan pemerintah kota sehingga sulit baginya untuk dapat memenuhi kebutuhankebutuhan yang mendesak dari dunia usaha yang sedang melebarkan sayapnya atau dari massa penduduk yang miskin ${ }^{11}$.

\section{METODE PENELITIAN}

Penelitian ini menggunakan metode kualitatif dengan pendekatan studi kasus. Studi kasus adalah suatu inquiri empiris yang menyelidiki fenomena dalam konteks kehidupan nyata, bilamana; batas-batas antar fenomena dan konteks tak tampak dengan tegas dan di mana: multi sumber bukti dimanfaatkan. Penelitian ini akan mengurai mobilisasi massa pendukung kolom kosong pada Pilkada 2018 di Kota Tangerang dan Kota Makassar. Pemilihan desain penelitian ini bersifat deskriptif analisis dalam menganalisa proses mobilisasi massa Rewako dan JKK dalam Pilkada 2018 di Kota Makassar dan Tangerang dan kemudian disajikan melalui kalimat dan data pasca wawancara yang dilakukan peneliti untuk menggambarkan tipe mobilisasi massa Rewako dan JKK dalam proses Pilkada 2018 tersebut. Hasil wawancara tersebut sesuai kaidah yang ada serta direduksi dan diverifikasi untuk kemudian disimpulkan sesuai data faktual yang diperoleh. Peneliti kemudian akan menjelaskan sesuai dengan latar belakang tema yang diteliti peneliti.

\section{HASIL DAN PEMBAHASAN}

\section{Proses dan Hasil Pilkada Serentak}

Kelompok pendukung kolom kosong pada faktanya merupakan akibat dari diperbolehkannya calon tunggal pada Pilkada. Hanya saja proses terjadinya calon tunggal bisa berbeda di 16 daerah tersebut, tak terkecuali Kota Makassar dan Kota Tangerang. Kota Makassar pada awalnya memiliki dua calon yaitu paslon Appi-Cicu dan DannyIndira yang ditetapkan KPUD. Selama proses kampanye, keduanya sama-sama menjanjikan program dan prestasi. Namun kurang lebih satu bulan sebelum pemilihan berlangsung, kubu paslon 1 Appi-Cicu melaporkan pelanggaran kampanye ke PT.TUN karena dianggap menggunakan program pemkot sebagai alat kampanye. Hal tersebut mengakibatkan terdiskualifikasinya paslon Danny-Indira atas putusan PT.TUN.

Pasca putusan itu, para pendukung Danny-Indira secara otomatis mengorganisir diri untuk membentuk kelompok-kelompok termasuk Relawan Kolom Kosong (Rewako) yang punya tujuan mengedukasi masyarakat terkait kotak kosong. Hingga pemilihan berlangsung, suara untuk kotak kosong tidak terbendung. Kotak kosong memenangkan pilkada Kota Makassar dengan perolehan 53,23\% atau 300.795 suara. Dengan hasil tersebut, Kota Makassar hingga 2020 dipimpin oleh Penanggung Jawab (PJ) dari Pemprov Sulsel yaitu, M. Iqbal Suhaeb.

Berbeda dengan Kota Tangerang, sejak penetapan pasangan calon ditutup, kontestasi hanya diramaikan oleh satu calon yaitu Arief-Sachrudin yang didukung oleh

${ }^{11}$ Loc Cit., Samuel P. Huntington dan Joan Nelson, hlm. 179 
10 partai yang ada di DPRD. Padahal sebelum penetapan, isu bahwa Sachrudin yang merupakan wakil walikota akan maju sebagai calon cukup kencang. Pasca penetapan itu lah Jaringan Kotak Kosong (JKK) lahir sebagai kelompok pendukung kolom kosong yang cukup gencar mengkampanyekan kolom kosong karena tidak puas terhadap kepemimpinan Arief Wismansyah pada periode sebelumnya. Hasilnya, AriefSachrudin mampu mengalahkan kolom kosong dengan perolehan 85,80\%.

\section{Identitas Kelompok Pendukung Kolom Kosong}

Rewako dan JKK memang lahir setelah ditetapkannya calon tunggal oleh KPU. Meskipun dengan proses yang berbeda, keduanya memiliki visi yang relatif sama yaitu mengedukasi masyarakat untuk memilih kolom kosong. Rewako di Kota Makassar lahir pada tanggal 5 Juni 2018 yang ditandai dengan deklarasi yang mereka lakukan di depan kantor DPRD. Anshar Manrulu seorang mantan politisi Gerindra ditunjuk menjadi koordinator kala itu. Meski barisan pendukung kolom kosong tidak hanya Rewako, namun Rewako cukup gencar melakukan kampanye hingga mendapat sorotan dari media, padahal seluruh aktifitas Rewako tidak dibiayai oleh Danny Pomanto. Mereka mengumpulkan dana melalui sumbangan dan dana usaha masyarakat. Mempersuasi masyarakat untuk memilih kotak kosong lewat cara yang edukatif. Sebetulnya tetap menjadi orientasi Rewako, karena pada dasarnya mereka menolak proses oligarki yang terjadi, sehingga dukungan terhadap Danny juga menunjukkan ketidakberpihakannya terhadap Appi- Cicu. Terdapat aktifis sosial lainnya seperti para aktifis AIDS yang terlibat dalam proses kampanye kotak kosong.

Jaringan Kotak Kosong merupakan kelompok yang didirikan atas kesamaan semangat bahwa masyarakat menolak proses demokrasi yang ditunggangi pelaku oligarki sehingga terjadi calon tunggal. Mereka memilih untuk mengedukasi masyarakat perihal kotak kosong yang baru dirasakan masyarakat Kota Tangerang. Tak hanya persoalan oligarki, mereka pun mengaku sangat tidak puas dengan kinerja dan kebijakan pada periode sebelumnya yang dipimpin Arief Wismansyah, sehingga mereka menolak untuk memilihnya pada Pilkada 2018. Secara kultural, mereka telah mengorganisir diri sejak penetapan KPUD terkait calon tunggal. Namun secara struktural, JKK terbentuk pada tanggal 09 Mei 2018 yang juga ditandai dengan deklarasi di Istana nelayan. Deklarasi tersebut melibatkan para aktifis, tokoh masyarakat, hingga tokoh agama. JKK menobatkan Saiful Basri sebagai korrdinator. JKK pun mengkritik partai politik yang secara dominan mendukung satu calon dan menutup potensi calon lain yang ingin bertanding. Hal ini yang kemudian harus menjadi dasar pilihan masyarakat bahwa tindakan oligarki sangat tidak layak untuk didiamkan, masyarakat punya kekuatan untuk merubah itu dengan memilih kotak kosong.

\section{Proses Mobilisasi Massa}

Sejak Rewako dideklarasikan, Rewako cepat melancarkan jaringan mereka guna memperkuat dukungan terhadap kolom kosong, karena mereka hanya memiliki waktu kurang lebih 3 minggu saja. Dengan menggunakan media whatsapp, informasi cepat 
tersalurkan sehingga membuat respon para relawan di daerah lain terasa cepat sekali. Maka dari itu, sosialisasi yang dilakukan Anshar terbilang efektif, di samping itu tingginya antusiasme para ibu-ibu yang terlibat di dalamnya membuat sosialisasi kerap dilakukan dari rumah ke rumah layaknya metode arisan dan pengajian. Respon buruk KPU Kota Makassar terkait sosialisasi kotak kosong justru memberikan semangat kepada Rewakountuk terus gencar memberikan sosialisasi.

Respon buruk KPU Kota Makassar terkait sosialisasi kotak kosong justru memberikan semangat kepada Rewako untuk terus gencar memberikan sosialisasi. ${ }^{12}$

"KPU tidak mau melakukan sosialisasi karena waktunya mepet. Rakyat yang bergerak memenangkan kotak kosong, janjian bertemu di anjungan pantai losari untuk meminta atribut untuk dia sosialisasikan di daerahnya. Dia datang menyebrang secara sukarela"

Anshar mengaku respon masyarakat begitu antusias walau dengan waktu yang singkat. Masyarakat bergerak dinamis untuk melakukan sosialisasi, mulai dari daerah perumahan, lorong, hingga daerah yang ditempuh lewat jalur laut. Peran masyarakat kelas menengah pun tak surut, sedari awal mereka tidak yakin dengan kefiguran Appi dalam konteks bisnis. Sehingga mereka memberikan penolakan pada Appi dengan cara memilih kotak kosong. Mobilitas masyarakat tidak hanya didominasi oleh masyarakat kelas bawah yang sebelumnya menjadi strong voter dari pasangan Danny-Indira. Tetapi terdapat peran-peran kelas menengah yang kemudian membuat gerakan pendukung kolom kosong menjadi sangat massif karena pesimis terhadap kefiguran Appi dalam mengawal pemerintahan.

Masifnya gerakan Rewako memang tak lepas dari pengaruh Danny Pomanto. Bagaimana program Danny sebagai walikota menjadi kunci kepercayaan dan elektabilitasnya sehingga mampu mendapatkan strong voters. Terbukti ketika Danny tak lagi menjadi peserta pilkada, pendukung Danny tetap setia berdiri di belakang sambil memberikan berbagai bentuk dukungan. Kondisi ini sesuai dengan teori patron-klien yang dijelaskan Huntington, bahwa Danny mampu menjadi patron yang baik di mata masyarakat sebagai kliennya dibandingkan dengan patron kuat lainnya yaitu Jusuf Kalla dan Aqsa Mahmud yang dalam pilkada kali ini berada di belakang Appi-Cicu. Proses politik yang terjadi menunjukkan bahwa kultur masyarakat Sulawesi khususnya kota Makassar sangat dipengaruhi oleh seseorang yang memiliki pengaruh besar. Selama menjadi walikota hingga saat ini Danny selalu menjadikan rumahnya sebagai rumah rakyat, masyarakat kota Makassar yang membutuhkan bantuan dalam bentuk uang, barang, dan jasa akan diproses bantuannya oleh Danny Pomanto.

Selama menjadi walikota hingga saat ini Danny selalu menjadikan rumahnya sebagai rumah rakyat, masyarakat kota Makassar yang membutuhkan bantuan dalam bentuk

\footnotetext{
${ }^{12}$ Wawancara dengan Anshar Manrulu, Ketua Rewako pada tanggal 20 November 2019 pukul 11.04 WITA di Warung Kopi 212
} 
uang, barang, dan jasa akan diproses bantuannya oleh Danny Pomanto. ${ }^{13}$

"Selama ini, rumah saya mulai dari subuh banyak yang datang. Ada yang butuh bantuan uang, ada mahasiswa yang bawa proposal, ada yang minta makan, sampai urusan adminitrasi. Dari setelah sholat subuh sampai jam 8 kira-kira, yang nginap juga ada, pasti disini ramai sampai sekarang, padahal saya sudah tidak jadi walikota lagi”

Sikap dan perilaku yang Danny lakukan pada masyarakat memang memberikan banyak manfaat. Akan tetapi dalam konteks hubungan sosial, secara tidak langsung Danny bertindak sebagai patron yang mampu memberikan berbagai bantuan yang dibutuhkan oleh masyarakat. Pertarungan politik yang terjadi di Makassar tidak terlihat memperlihatkan pertarungan gagasan, melainkan pertarungan patron. Patron yang memiliki pengaruh lebih besar akan memberikan kekuatan politik bagi kubu tersebut. Appi yang merupakan menantu dari Jusuf Kalla dan sekaligus anak dari pemilik Bosowa, memiliki modal politik yang cukup untuk menantang Danny Pomanto sebagai petahana.

Tidak hanya dalam hubungan Danny dan masyarakat Kota Makassar. Pertarungan politik yang terjadi di Makassar tidak terlihat memperlihatkan pertarungan gagasan, melainkan pertarungan patron. Patron yang memiliki pengaruh lebih besar akan memberikan kekuatan politik bagi kubu tersebut. Appi yang merupakan menantu dari Jusuf Kalla dan sekaligus anak dari pemilik Bosowa, memiliki modal politik yang cukup untuk menantang Danny Pomanto sebagai petahana.

Tidak berhenti pada tahap tersebut, hasil wawancara peneliti dengan juru bicara Danny yaitu Maqbul Halim, mengkonfirmasi bahwa masyarakat kota Makassar masih menginginkan dipimpin oleh Danny Pomanto pada Pilkada 2020 nanti. ${ }^{14}$

"Kami sudah mempersiapkan diri, melakukan gerakan bawah tanah dengan Tagline 'Tungguma' yang berarti tunggu saya!, kalau dulu kan masih 'Tunggumi' (Tunggu saja). Dan gambar-gambar tersebut kami share, masyarakat yang blast ke whatsapp grup hingga viral."

Kondisi tersebut menguatkan bahwa terdapat hubungan yang erat nan konsisten antara Danny Pomanto dan masyarakat kota Makassar yang akan terus berlanjut hingga pilkada 2020. Kekalahan calon tunggal di kota Makassar memang dominan dipengaruhi oleh mobilitas pendukung kolom kosong yang masif. Tapi juga ada faktor-faktor lain seperti yang diakui oleh ketua timses sekaligus mantan ketua DPRD kota Makassar, Farouk M Betta. ${ }^{15}$

\footnotetext{
${ }^{13}$ Wawancara dengan Danny Pomanto, Walikota Makassar 2014-2019 pada tanggal 18 November 2019 pukul 09.18 WIB di Kediaman Beliau Jl. Amirullah

${ }^{14}$ Wawancara dengan maqbul halim, jubir Danny Pomanto pada tanggal 18 November 2019 pukul 18.31 WITA di Kediaman Bapak Danny Pomanto J1. Amirullah

${ }^{15}$ Wawancara dengan Farouk M Betta, Ketua Timses Appi-Cicu pada tanggal 25 November 2019 pukul 13.59 WITA di Kediaman Beliau Kompleks Galdiol B/12
} 
"Gaya politik Appi memang keliru. Dia gak bisa menghargai partai-partai koalisi. Seharusnya cara komunikasi politik yang baik ya dengan sowan ke partai-partai lain. Tapi Appi hanya fokus di Golkar saja. Padahal sebagai partai pendukung kami sudah selalu mengingatkan dia"

Akibat dari kekeliruan gaya politik yang dilakukan Appi, tak sedikit para politisi dari partai-partai koalisi justru resisten. Anshar Manrulu mengakui, ada banyak politisipolitisi dari para partai koalisi justru memilih untuk mendukung Danny dan kolom kosong. Akan tetapi, karena kekecewaannya terhadap keputusan partai dan gaya politik Appi, maka mereka memilih mbalelo dari tugasnya untuk mengkampanyekan AppiCicu. Sehingga menurut keterangan Anshar, anggota kelompok pendukung kolom kosong tidak hanya diisi oleh mantan pendukung Danny Pomanto, tapi juga ada kelas menengah yang meliputi pengusaha dan para anggota partai yang kecewa. Terdapat pula para akademisi yang kecewa dengan proses putusan pencalonan dari KPU. Sehingga semuanya terakumulasi menjadi suara pendukung kolom kosong.

Meski JKK meraih hasil yang berbeda dengan Rewako di Kota Makassar. Gerakan JKK tak berhenti hanya pada deklarasi, mereka menguatkan jaringan dengan membentuk koordinator mulai dari kecamatan hingga ranting. Dengan motif edukasi, JKK memulai pendekatan dengan cara memberikan sosialisasi tentang kotak kosong yang terbilang minim sekali dilakukan oleh KPU sebagai pemangku wewenang terkait tahapan pilkada. Kemudian menunjukkan rapor merah Arief Wismansyah selama menjabat walikota Tangerang periode 2013-2018 yang dianggap tidak layak dipilih kembali sebagai walikota. JKK mendapat respon positif dari masyarakat, terlihat dari antusiasme dalam mengikuti sosialisasi. Saiful Basri selaku koordinator JKK tidak hanya berdialog dengan masyarakat secara umum, ia juga bertemu dengan tokoh agama, tokoh masyarakat dan tokoh budaya, sehingga dukungan yang mengalir cukup deras. Variasi dukungannya bermacam-macam, dari khotbah tokoh agama tentang kolom kosong, hingga arransement musik senam yang dirubah menjadi musik dukungan terhadap kolom kosong. Variasi tersebut ditujukan untuk menjangkau pemilih-pemilih lain yang memiliki interpretasi yang berbeda.

Dengan struktur yang dimiliki JKK, gerakan sosialisasi terasa lebih mudah. Koordinator Kecamatan hingga ranting memiliki tugas masing-masing. Koordinator kecamatan menyiapkan materi sosialisasi dan menggalang dana usaha. Koordinator kelurahan menyiapkan tempat dan jadwal. Koordinator ranting punya tugas mengumpulkan serta memobilisasi massa. Meskipun pada akhirnya proses sosialisasi tetap terlihat seperti kegiatan RT dengan logistik dan peralatan seadanya. Secara jumlah, mereka berhasil memiliki 10 koordinator Kecamatan dari 13 Kecamatan yang ada.

Keterlibatan elit politik dalam gerakan JKK dianggap pasif. Bukan hanya karena tidak pernah terlibat langsung dalam gerakan, tapi dukungan yang diberikan hanya sekedar semangat. Elit politik yang ada tidak memberikan bantuan apapun baik fisik 
maupun finansial. Sehingga sekalipun ditemukan elit yang tidak mendukung calon tunggal, dapat dipastikan ia juga tidak memberikan bantuan kepada JKK, dikarenakan takut akan jaringan dan kepentingan bisnisnya bisa terganggu. Akhirnya, Seluruh kebutuhan pembiayaan yang diperlukan JKK dipenuhi melalui sumbangan masyarakat (patungan) dan beberapa kegiatan dana usaha.

"Elit politik gak mau terlibat karena takut bisnis dan karir politiknya terganggu, walaupun ada yang jelas bersebrangan dengan pak Arief, tetap saja tidak ada bantuan sama sekali. Semua dana yang kita gunakan berasal dari patungan teman-teman, selain itu Alhamdulillah kita punya dana usaha berupa warung yang hasilnya bisa kita gunakan untuk kebutuhan sosialisasi selama masa kampanye."16

Pada prinsipnya, JKK hanya ingin mengedukasi masyarakat kota Tangerang tentang demokrasi, dalam hal ini kondisi Pilkada Serentak 2018. Bahwa masyarakat punya peran utama dalam menentukan masa depan Kota Tangerang. Secara politik, suara masyarakat tidak boleh digunakan atau ditukar dengan janji dan biaya sebesar apapun. Alhasil sosialisasi yang dilakukan lebih mengarah pada hak masyarakat, terlebih lagi kondisi yang dialami masyarakat kota Tangerang kemarin adalah kondisi krusial. Kondisi yang dalam beberapa pemahaman masyarakat menganggap hanya ada satu calon yang sah untuk dipilih, memilih kolom yang tidak bergambar sebagai golput, dan lain sebagainya. Hal ini lah yang kemudian ingin dirubah persepsinya oleh kelompok JKK. Selain itu, masyarakat juga perlu dicerdaskan dalam memilih calon. Calon harus sungguh-sungguh dipertimbangkan kefiguran, kinerja dan latar belakangnya, bukan dari identitasnya. JKK memberikan informasi kepada masyarakat bahwa kondisi kota Tangerang dalam periode 2013-2018 tidak menunjukkan adanya perubahan yang signifikan mengarah pada pembangunan sosial maupun infrastruktur. ${ }^{17}$

"Sebelum ada JKK pun kita sering demo di walikota, sering mengkritik kebijakan-kebijakan pemerintah. Jadi memang tujuan kita untuk mencerdaskan masyarakat bahwa kita berhak menentukan pemimpin yang kita mau, yang berintegritas, yang bersih, yang adil. Karena Arief selama periode lalu punya rapor merah yang banyak, maka kami gk mau pilih dia lagi, lebih baik kita pilih kotak kosong. Kubu sebelah juga melakukan penggembosan dengan narasinarasi kalau pilih kotak kosong itu gak sah, golput, dll.”

Saiful Basri juga menegaskan bahwa tujuan gerakan JKK memang diwarnai oleh kekecewaan terhadap oligarki yang dibangun oleh sang petahana. Arief berhasil memborong 10 partai yang ada di DPRD, sehingga menutup calon lain yang akan bertanding melalui jalur partai. Di sisi lain, jalur perseorangan lebih sulit didapatkan.

\footnotetext{
${ }^{16}$ Wawancara dengan Saiful Basri, Koordinator JKK pada tanggal 25 Oktober 2019 pukul 16.29 WIB di Danau Situ Gede

${ }^{17}$ Wawancara dengan Saiful Basri, Koordinator JKK pada tanggal 25 Oktober 2019 pukul 16.29 WIB di Danau Situ Gede
} 
Karena tidak adanya keterlibatan elit politik dan kelas menengah seperti pengusaha. Gerak-gerik JKK sangat terbatas dari segi finansial. Mereka hanya menutupi kebutuhannya melalui iuran dan sumbangan dari para anggota serta masyarakat lainnya. Sehingga membuat JKK tidak menyalurkan materi kampanye terkait kotak kosong melalui banyaknya spanduk atau pamflet, melainkan menggiatkan setiap kegiatan sosialisasi dan aksi yang dilakukan JKK melalui kanal-kanal media lokal, grup whatsapp, dan media sosial facebook. Hambatan JKK tidak hanya soal finansial, juga hantaman dari kubu calon tunggal. Kubu calon tunggal melakukan framing dengan narasi bahwa memilih kotak kosong merupakan tindakan inkonstitusional dan tidak sah. Para ASN juga diduga terlibat dalam penggembosan gerakan JKK seperti penolakan yang dilayangkan oleh lurah setempat.

Dalam proses sosialisasinya, JKK memang memprioritaskan sosialisasi bahwa masyarakat sah untuk memilih kotak kosong apabila tidak menemukan kecocokan pada calon tunggal. Hal ini dilakukan agar JKK tidak dianggap memprovokasi dengan kepentingan politik tertentu, sehingga tidak menciptakan resistensi. Saat masyarakat telah menerima dengan baik, JKK mengajak masyarakat untuk mengevaluasi serta menilai kinerja dan kefiguran walikota saat ini, dengan maksud memberikan arahan bahwa masyarakat memang berhak mengganti walikota apabila dinilai tidak baik, yang kemudian direspon baik oleh KPUD. ${ }^{18}$

"Saya pribadi tidak mengetahui persis adanya gerakan kotak kosong, tetapi riak-riak di masyarakat ada. Justru kita merasa terbantukan dengan adanya kelompok kotak kosong yang mensosialisasikan kolom tidak bergambar yang ada pada pilkada kali ini. Bahkan perlu adanya pembaharuan kajian sehingga kelompok kotak kosong perlu difasilitasi kedepannya."

Kunci kekalahan kotak kosong di kota Tangerang ialah karena proses mobilisasi massa yang dilakukan tim calon tunggal lebih terukur dan efektif. Dengan modal popularitas dan elektabilitas yang tinggi sebagai petahana, timses relatif lebih mudah untuk mempersuasi dan melancarkan kampanye terkait visi, misi, dan program dari calon tunggal melalui perangkat-perangkat yang mereka miliki. Sedangkan JKK dengan segala keterbatasan, hanya mampu meraih 102.386 suara.

Pasca ditetapkannya Arief-Sachrudin sebagai pemenang Pilkada, JKK berdiri sebagai oposisi pemerintahan yang senantiasa memberikan saran dan kritik terhadap seluruh kebijakan pemerintah kota Tangerang dalam bentuk apapun. JKK tak menampik, pada pilkada yang akan datang, mereka akan selalu siap pada apapun kondisi politiknya. Apabila calon tunggal terjadi kembali, maka JKK akan tetap berperan sebagai wadah pencerdasan dan perlawanan kepada oligarki yang semakin subur. Di sisi lain, JKK juga mempersiapkan diri untuk mengusung calon baru yang lebih kompeten dan berintegritas, agar menghindari kekuatan oligarki yang diperankan oleh para elit dan partai politik selama ini di lingkungan Kota Tangerang.

18 Wawancara dengan Ahmad Syailendra ketua KPU Kota Tangerang pada tanggal 25 Oktober 2019 pukul 10.16 WIB di kantor KPU Kota Tangerang 


\section{Implikasi Gerakan Rewako dan JKK Terhadap Demokrasi Lokal}

Huntington menjelaskan bahwa hubungan patron-klien adalah hubungan timbal balik meski timpang. Patron yang berada di posisi yang tinggi akan memberikan bantuan berupa uang, barang, jasa serta keuntungan ekonomi. ${ }^{19}$ Dalam konteks mobilisasi politik, peran yang dilakukan Danny Pomanto menjadikannya sebagai patron. Bahwa patron mampu memberikan berbagai bantuan kepada kliennya seperti kebutuhan uang, barang, atau jasa. Peran patron ini lah yang kemudian terkonversi menjadi dukungan dalam proses pilkada yang berlangsung di kota Makassar. Menguatnya hubungan Danny dengan masyarakat ditandai dengan mengalirnya dukungan untuk mencalonkan kembali pada pilkada 2020. Masyarakat Makassar menilai Danny masih layak untuk memimpin kota Makassar dengan program dan kebijakan yang selama periode 2014-2019 berpengaruh pada pembangunan kota Makassar. Hal ini menunjukkan bahwa ikatan patron-klien yang terbangun tidak terhenti hanya karena sang patron tidak lagi menjabat. Justru patron akan terus berpengaruh dalam aktifitas masyarakat yang erat kaitannya dengan politik.

Hubungan patron-klien yang diperankan oleh Danny Pomanto pada dasarnya menjadi suatu hal yang wajar. Sikap dan keberpihakannya pada masyarakat bisa menjadi hal positif dalam mempertahankan dirinya sebagai patron yang selalu didukung oleh kliennya. Beberapa daerah lain juga akan memiliki figur yang dianggap masyarakat cocok untuk berperan di lingkungan sekitarnya, sehingga mampu didorong menjadi pemimpin setempat. Hanya saja hubungan patron-klien yang dilatarbelakangi oleh kekuatan bisnis acap kali memberikan pengaruh yang cenderung buruk. Patron yang totaliter akan tetap didukung oleh kliennya. Klien juga cenderung akan menjadi strong voters bagi si patron.

Dalam konteks pilkada, fenomena tersebut akan mengakibatkan minimnya regenerasi calon-calon dengan gaya pemimpin dan gagasan baru. Kontestasi akan selalu diwarnai oleh seberapa kuat pengaruh patron terhadap masyarakat, bukan seberapa gemilang gagasan dan program yang ia tawarkan kepada publik secara umum. Selain unsur patron-klien, rewako dalam karakteristiknya juga menunjukkan bahwa aktifitas politik yang ia lakukan mengindikasikan Rewako sebagai mesin politik dari kubu Danny Pomanto. Mesin politik mengindikasikan bahwa tujuan politiknya ialah mengakselerasi kepentingan elit atau patron dari klien itu sendiri.

Peneliti menganggap bahwa hubungan patron-klien dan mesin politik perlu diberikan batas. Bahwa ketika patron memiliki kepentingan politik atau bisnis lain yang justru tidak memberikan dampak baik terhadap masyarakat secara umum, maka klien harus cerdas untuk memutus hubungan tersebut.

Bagi Huntington, proses mobilisasi massa yang terjadi di Kota Tangerang merupakan tipe partisipasi yang otonom. Partisipasi otonom mengindikasikan bahwa adanya proses mobilisasi yang berasal dari kesadaran masyarakat tanpa intervensi kepentingan dari pihak lain termasuk elit politik dari partai. Gerakan yang dilakukan

${ }^{19}$ Loc. Cit. Huntington, hlm. 178 
kelompok masyarakat dengan partisipasi otonom biasanya tidak dalam paksaan (instruktif) dalam mewujudkan kepentingannya. ${ }^{20}$ Sedangkan untuk JKK, perannya pada pilkada kota Tangerang ialah memobilisasi massa secara terstruktur tanpa intervensi elit partai politik manapun. Sehingga JKK mampu leluasa dalam menentukan kebijakan yang mengarah pada perwujudan kepentingan politiknya yaitu memenangkan kolom kosong melawan calon tunggal. JKK tidak memiliki patron dari partai politik yang mampu memberikan bantuan yang dibutuhkan oleh masyarakat kota Tangerang. Di sisi lain, posisi JKK sebagai oposisi pemerintahan menguatkan kecenderungan bahwa memang ia diciptakan sebagai kelompok yang akan terus memberikan perlawanan terhadap calon tunggal yang memenangkan pilkada tanpa dukungan dari kelas menengah.

Dalam konteks demokrasi lokal, peneliti beranggapan bahwa tipe gerakan JKK yang merupakan partisipasi otonom perlu dipertahankan sebagai sarana aspirasi dan bentuk input terhadap kebijakan- kebijakan yang dikeluarkan oleh pemerintah daerah dengan independen. Hal ini perlu digaungkan kembali di saat para LSM dan lembaga mahasiswa justru menjadi perpanjangan tangan pemerintah yang pada akhirnya akan mereduksi independensi dalam merespon kebijakan pemerintah dikarenakan takut untuk melakukan kritik. Peneliti berpendapat bahwa kelompok otonom di era sekarang kerap kali pada akhirnya dikooptasi oleh partai dan afiliasinya sehingga tak lagi memiliki integritas dan prinsip kerakyatan. Mereka hanya diciptakan untuk mengikuti perintah dari elit politik sesuai dengan kepentingan partai. Kondisi ini perlu dijauhkan dari masyarakat, sebab dampak buruknya ialah menutup celah dalam mengembangkan kecerdasan publik dalam merespon kebijakan penguasa (pemerintah) dengan objektif.

Figur 1. Perbandingan Rewako dan JKK

\section{Relawan Kolom Kosong Jaringan Kotak Kosong (Jkk) (Rewako) Kota Makassar Kota Tangerang}

Tipe Mobilisasi Tipe Patron-Klien dan Tipe Partisipasi Otonom; mesin politik;

Ketua/Elit Politik Anshar Manrulu Saiful Basri

Danny Pomanto

$\begin{array}{lll}\begin{array}{l}\text { Kepentingan } \\ \text { Politik }\end{array} & \begin{array}{l}\text { Mendukung Danny } \\ \text { Pomanto untuk }\end{array} & \begin{array}{l}\text { Mengedukasi Masyarakat } \\ \text { dengan Menjadi Oposisi }\end{array} \\ & \text { mencalonkan kembali } & \text { Pemerintah Kota Tangerang } \\ & \text { pada Pilkada Kota } & \\ & \text { Makassar 2020. } & \end{array}$

Sumber: Diolah oleh Peneliti tahun 2019

${ }^{20}$ Loc. Cit., Huntington, hlm. 13 


\section{KESIMPULAN}

Proses mobilisasi yang dilakukan oleh Rewako dan JKK mampu memberikan peran khusus sebagai bukti perlawanan terhadap oligarki di tingkat elit politik. Kemenangan Rewako di Kota Makassar tak hanya menorehkan sejarah baru dalam pemilu tanah air, melainkan menjadi pukulan telak kepada elemen-elemen yang terlibat seperti KPU sebagai penyelenggara, Partai sebagai peserta, dan Elit politik sebagai pendukung. Kemenangan tersebut tak lepas dari masifnya peran dari Rewako dan kelompok pendukung kotak kosong lainnya yang merupakan mantan dari pendukung Danny Pomanto dalam memobilisasi serta mempersuasi masyarakat kota Makassar. Juga figur Danny selama menjadi walikota hingga sekarang masih disukai oleh sebagian besar masyarakat Kota Makassar. Berbeda dengan Makassar, gerakan JKK di Kota Tangerang tidak ditemukan pengaruh dari elit politik. Hanya saja sebagian dari anggota JKK adalah pendukung Sachrudin kala masih menjadi bakal calon walikota, yang kemudian kecewa karena bergabung dengan Arief Wismansyah sebagai calon wakil walikota. JKK tetap mampu melakukan konsolidasi ke seluruh kecamatan hingga terbentuk koordinator kecamatan, kelurahan, dan ranting. Meskipun kalah, JKK mampu memberikan perlawanan kepada calon tunggal.

Berdasarkan teori Huntington, Rewako dan kelompok pendukung kolom kosong di Makassar dinilai oleh peneliti sebagai bentuk mobilisasi patron-klien. Sebab Danny Pomanto sebagai kandidat pilihan mereka digagalkan, sehingga mereka secara otomatis berupaya memenangkan kotak kosong. Sedangkan JKK di Tangerang, mereka menjadikan masyarakat kelas menengah ke bawah sebagai sasaran dari upaya mobilisasinya dengan melakukan sosialisasi. Mekanisme gerakan mereka yang memberikan kesempatan pada masyarakat kelas menengah ke bawah untuk cerdas terlibat dalam pemilu, membuat peneliti menganggap proses mobilisasi mereka sebagai mobilisasi mesin politik. Selain itu, peneliti juga menegaskan bahwa kelompok kotak kosong akan semakin masif apabila perilaku politik partai dan elit politik masih melakukan tindakan yang melanggengkan oligarki politik. Kajian yuridis, tentang keberadaan kotak kosong juga ditekankan peneliti, bahwa perlu adanya pembaharuan akademis dalam menyusun peraturan serta undang-undang kepemiluan, sehingga kelompok-kelompok seperti ini diberikan ruang lebih untuk berperan. Dengan begitu, tingkat partisipasi masyarakat yang kian menurun akan mulai terkatrol, dan mampu mengembalikan amanat demokrasi yang memberikan kedaulatan seutuhnya dari, oleh, dan untuk rakyat.

\section{DAFTAR PUSTAKA}

Agustino, Leo. 2007. Perihal Ilmu Politik:Sebuah Bahasan Memahami Ilmu Politik. Yogyakarta: Graha Ilmu

Ananda, Moh. Fachrul, Mobilisasi Politik: Ormas dalam Kontestasi Politik Pemilihan Gubernur Jawa Timur 2018. Jurnal Fakultas Ilmu Sosial dan Ilmu Politik Universitas Airlangga P.14 No. 19

Aspinall, Edward dan Mada Sukmajati. 2015. Politik Uang di Indonesia, Patronase dan 
Klientalisme pada Pemilu Legislatif 2014. Yogyakarta: PolGov.

Banducci, Susan A. dan Jeffrey A. Karp. 2007 Party Mobilization And Political Participation In New and Old Democracies. London: Jurnal Party Politics Vol 13. No 2 pp. 217-234

Budiardjo, Miriam. 1981. Partisipasi dan Partai Politik.Jakarta: Gramedia

--------. 2008. Dasar-Dasar Ilmu Politik.Jakarta: Gramedia

Bungin, Burhan. 2003 Analisa Data Penelitian Kualitatif, Jakarta: PT. RajaGrafindo Persada

Creswell, John W. 2014. Research Design: Pendekatan Kualitatif, Kuantitatif, dan Mixed. Yogyakarta: Pustaka Pelajar

Darmawan, Ikhsan. 2017. Peran dan Strategi Kelompok "Kotak Kosong” dalam Pilkada Calon Tunggal Kabupaten Pati Tahun 2017:Studi Pendahuluan. Depok: Jurnal Wacana Politik Volume 2 No. 1

Dwiana, Ressi. 2013. Mobilisasi Massa Dalam Era Network Society. Jurnal Pekommas Vol. 16, No. 3

Eggy, I Kadek, dkk. 2014. Mobilisasi Massa Melalui Tajen Dalam Pemilihan Umum Legislatif Tahun 2014 Di Kabupaten Tabanan. Jurnal Fakultas Ilmu Sosial dan Ilmu Politik Universitas Udayana

Heywood, Andrew. 2014. Politik Edisi ke-4. Yogyakarta: Pustaka Pelajar

Huntington, Samuel P. dan Joan Nelson. 1990. Partisipasi Politik di Negara Berkembang. Jakarta: Rineka Cipta

Janice M. Morse. 2000. Qualitative Nursing Research: A Contemporary Dialogue. Newbury Park. CA: Sage

K. Yin, Robert. 2012. Studi Kasus, Desain dan Metode. Jakarta: PT Raja Grafindo Persada Kumolo, Tjahjo. 2015. Politik Hukum Pilkada Serentak. Jakarta: PT Mizan Republika Moleong, Lexy J. 2004. Metodologi penelitian kualitatif, Bandung: Remaja Rosdakarya

Muhammad Elwin, La ode. 2019. Model dan Dampak Mobilisasi Politik Pemilihan Kepala Desa (Studi Kasus: Desa Bontomatinggi Kabupaten Maros Sulawesi Selatan Tahun 2016. Jurnal Public Uho FISIP Vol. 1, No. 4

Pratama, Rekha Adji. 2017. Patronase Dan Klientalisme Dalam Relasi Walikota, Pejabat Birokrasi, dan Masyarakat di Kota Kendari tahun 2017. Yogyakarta: Universitas Gadjah Mada Jurnal Wacana Politik Vol 2 No. 1

RI, Bawaslu. 2018. Fenomena Calon Tunggal Studi Kasus pada Pilkada 2018 di 16 Kota/Kabupaten. Jakarta: Bawaslu RI

Sugiyono. 2005. Metode Penelitian Kuantitatif, Kualitatif, Dan R\&D. Bandung: Alfabeta

Sukandarrumidi, Haryanto. 2014. Dasar-Dasar Penulisan Proposal Penelitian. Yogyakarta: Gadjah Mada University Press

Susanti, Naomi. 2017. Peran GP Ansor Sidoarjo Dalam Pilkada: Studi Mobilisasi Politik Untuk Pencalonan Kepala Daerah Kabupaten Sidoarjo 2015. Jurnal Politik Muda, Vol. 6, No. 3

Tesis Dari Mayangsari, Dewi. 2019. Kompetisi Elit Politik Pada Pemilihan Calon Tunggal Walikota dan Wakil Walikota Makassar Tahun 2018. Tesis S2 Fakultas Ilmu Sosial dan Ilmu Politik Universitas Indonesia

Tesis Dari Nisa, Khoerun Fadillah. 2019. Pembangunan Koalisi Partai Pengusung Calon Tunggal Dalam Pemilihan Kepala Daerah Kabupaten Tangerang Tahun 2018. Tesis S2 Fakultas S2 Fakultas Ilmu Sosial dan Ilmu Politik Universitas Indonesia, Juni 2019 